\title{
ARTIKELEN
}

\section{Het antropoceen}

\section{De criminologische uitdaging in de 21ste eeuw}

\author{
Janine Janssen \& Marc Schuilenburg
}

\section{Aanleiding}

Het antropoceen is een concept dat de laatste jaren aan een flinke opmars bezig is en veel bekendheid geniet in kritisch kringen waar zorg heerst over de toekomst van de planeet. De term werd in 2000 geïntroduceerd door de onlangs overleden Nederlandse atmosfeerchemicus en Nobelprijswinnaar Paul Crutzen (1933-2021) voor het geologische tijdperk waarin wij nu leven. Crutzen ontving de Nobelprijs in 1995 voor de ontdekking van de rol van stikstofoxides in de afbraak van de ozon in de stratosfeer. Het gevolg van het ozongat is dat de bescherming van het leven op aarde afneemt. Met de term 'antropoceen' wijst Crutzen erop dat we een nieuw tijdperk zijn binnengetreden waarin de invloed van de mens op atmosferische, biologische en geologische processen overal aanwezig is en waarvan we de effecten tot in lengte van eeuwen gaan ervaren. Het antropoceen is daarmee de opvolger van het Holoceen, het tijdvak na de laatste ijstijd dat zich kenmerkte door een vrij stabiel klimaat. Anthropos betekent 'van de mens' en 'antropoceen' maakt duidelijk dat de mens een geologische kracht van formaat is geworden die zich kan meten met natuurkrachten. Zo stelde VN-natuurorganisatie IPBES in 2019 in een vuistdik rapport dat $75 \%$ van de aardoppervlakte en $66 \%$ van de oceanen ernstig is aangetast door menselijk handelen. Volgens ecologen en biologen is de intensivering van tal van menselijke activiteiten, zoals landbouw, ontbossing en vervuiling, de drijvende kracht achter de ineenstorting van ecosystemen die van vitaal belang zijn voor het voortbestaan van mens en dier.

Volgens Crutzen vangt het antropoceen aan in het begin van de negentiende eeuw als de Industriële Revolutie in een stroomversnelling komt en de hoeveelheden $\mathrm{CO}^{2}$ en methaan in de lucht drastisch toenemen en voor het eerst boven de natuurlijke variatie uitstijgen. Dit komt door menselijk handelen, waaronder de verbranding van aardolie, gas en kolen, intensieve veehouderij en landbouw, en grootschalige houtkap. Door de uitstoot van broeikasgassen als methaan en $\mathrm{CO}^{2}$ denken we bij het antropoceen meteen aan klimaatopwarming. Maar de term is tegenwoordig ook synoniem voor zaken als luchtvervuiling, oceaanverzuring, ontbossing en de enorme afname van biodiversiteit. Alle lichten staan namelijk op rood. Volgens de meest recente inzichten worden op dit moment ongeveer een miljoen plant- en diersoorten met uitsterven bedreigd. Deze zogenaamde zesde uitstervingsgolf kan in veel gevallen al binnen enkele jaren tot een paar decennia zich voltrekken. Of, zoals journalist David Wallace-Wells het verwoordde in zijn bestseller The Uninhabitable Earth uit 2019: 'Here, the facts are hysterical.' Inmiddels is de term 'antro- 
poceen' opgepikt door tal van wetenschappelijke en beleidsdisciplines, van de economische en sociale wetenschappen tot het feminisme en het grotestedenbeleid, en zijn er allerlei tijdschriften opgericht die zich louter richten op de impact van het antropoceen, van Anthropocene tot The Anthropocene Review.

\section{Wetenschappelijk debat}

De groeiende populariteit van de term 'antropoceen' komt niet zonder wetenschappelijk debat. Een van de meest verhitte discussies gaat over de naamgeving van het nieuwe tijdvak en over de vraag wanneer we het begin ervan moeten situeren. In hun boek The shock of the Anthropocene (2017) sommen de Franse historici Christophe Bonneuil en Jean-Baptiste een hele reeks van andere namen op voor het huidige tijdperk, waarvan 'kapitaaloceen', oorspronkelijk gemunt door Andreas Malm (Malm \& Hornborg, 2014; Malm, 2016) en Matthew Huber in het artikel 'Energizing historical materialism' (2008), het meest tot de verbeelding spreekt. Voorstanders van de naam 'kapitaaloceen', waaronder de Canadese publiciste Naomi Klein (2014) en historisch geograaf Jason Moore (2015, 2017), menen dat klimaatverandering een product is van het kapitalistische systeem, met zijn wortels in de Europese expansie in de vijftiende en zestiende eeuw, waarbij over de hele wereld inheemse volkeren werden onderworpen aan de macht van witte kolonisten. Donna Haraway merkt in dat opzicht op: 'I think we are looking at slave agriculture, not coal, frankly, as a key transition' (2016: 555).

Klein en Moore stellen dat het antropoceen vooral een geologische - en daarmee historische - notie is, die onvoldoende duidelijk maakt dat aan klimaatverandering een concreet politiek vraagstuk ten grondslag ligt. Daarentegen wijst kapitaaloceen juist op de destructieve gevolgen van het kapitalisme en een ongelijk deel in de oorzaken en gevolgen van klimaatverandering. Zo wordt in het kapitalisme van alles een object gemaakt dat kan worden ge- en verkocht, denk aan het kappen van regenwoud voor consumptiegoederen ('commodificatie'). Tegelijk, en dat wordt accumulatie genoemd, staat het huidige systeem in het teken van zo veel mogelijk spullen kopen, groeien en winst maken (Hassler-Forrest, 2019). Kortom, draait de klimaatopwarming in de kern niet om de kwestie dat juist de hegemonie van de westerse wereld Moeder Aarde de das heeft omgedaan? Daarom schrijft Moore (2015: 175):

'To locate the origins of the modern world with the rise of capitalist civilization after 1450, with its audacious strategies of global conquest, endless commodification, and relentless rationalization, is to prioritize the transcendence of the relations of power, knowledge, and capital that have made - and are now unmaking - the modern world as we have known it.'

Om de verdere vernietiging van ecosystemen tegen te gaan is het noodzakelijk dat volgens Klein en Moore het kapitalisme op de schop gaat. Dit betekent, in navolging van de oproep van Franse filosoof en psychoanalyticus Félix Guattari in The Three Ecologies (2000), dat het ecologische vraagstuk niet langer wordt beperkt tot de natuurlijke omgeving, maar ook draait om de culturele en politieke kwestie om 
de parameters van de kapitalistische samenleving te verschuiven richting meer inclusieve vormen van samenzijn en productie. Kritiek is er ook op de term 'kapitaaloceen'. Goed beschouwd is het kapitalisme ook een menselijke activiteit en de enorme roofbouw van de natuur die tot wereldwijde kaalslag heeft geleid, vond ook plaats in communistische landen, waaronder de voormalige Sovjet-Unie, Oost-Europa en het huidige China.

\section{Corona: een verhaal van vele crises}

Hoe triviaal het ook mag klinken, discussies over de naam en schaal van het huidige tijdperk zijn belangrijk omdat, zo schrijven Marc Schuilenburg en Sjoerd van Tuinen in de bundel Leven in het antropoceen, ze 'ons beeld van het antropoceen onmiddellijk oriënteren: wat is er gebeurd, wie heeft het gedaan, waar moeten we naartoe?' (2019: 13). In dat licht drukt de coronapandemie ons met de neus op het feit dat nu verschillende crises in elkaar doorwerken en met elkaar verknoopt raken. Onder de coronacrisis gaat immers een ecologische crisis schuil die duidelijk werd toen het coronavirus, hoofdverdachte is de Chinese hoefijzervleermuis, oversprong van dier naar mens. Zoönosen zijn van alle tijden, van ebola en hondsdolheid tot de Mexicaanse griep, maar door de aanhoudende en grootschalige ontbossing van onze planeet, in samenspel met de handel en consumptie van wilde en exotische dieren, wordt het steeds makkelijker dat virussen overspringen naar de mens. Tegelijk hebben de effecten van de coronacrisis alles van doen met de manier waarop we onze wereldeconomie hebben ingericht. De pandemie volgt de patronen van het vrijemarktkapitalisme, het coronavirus lift als het ware mee op de lange ketens van de wereldeconomie, van internationale handelsstromen tot de verplaatsing van productieprocessen naar andere delen van de wereld om belastingen te ontwijken en arbeidskosten te verminderen (Schuilenburg, 2020). Die nuchtere feiten nopen tot de vraag hoe de mens zijn omgang met de natuur drastisch kan herzien en herijken.

Wanneer de mens zelf het dodelijkste virus is, wordt het de hoogste tijd om de implicaties van het antropoceen goed te doordenken. De kracht van de term 'antropoceen' is immers tweeledig: enerzijds maakt die term duidelijk dat we de rampen, die we niet alleen over onszelf maar ook over soorten en ecosystemen hebben afgeroepen, grotendeels aan ons zelf te danken hebben. In dat licht kunnen 'natuurrampen' beter 'mensenrampen' worden genoemd, ook omdat een ongerepte natuur in de zin van een apart en zelfstandig domein niet langer is te vinden. Anderzijds doet de nadruk op de factor 'mens' ook een beroep op onze morele verantwoordelijkheid om te proberen - voor zover dat nog kan - het tij te keren. Verklaren is een ding, we zullen ook wat moeten gaan doen. Dient bijvoorbeeld ecocide strafbaar te worden gesteld, het toebrengen van onherstelbare schade aan de natuur? Moet de politiek op de proppen komen met een Green New Deal, een radicale klimaataanpak in combinatie met sociale en economische hervormingen? Kunnen we van de Veluwe een rechtspersoon maken, een natuurgebied met eigen rechten? 


\section{Non-speciesisme: voorbij onderscheid mens-dier}

Voordat we aan een beantwoording van dergelijke vragen toekomen, is het belangrijk om in te zien dat in het antropoceen natuur en mens niet langer als twee verschillende entiteiten tegenover elkaar kunnen worden geplaatst. Zo blijkt uit tal van studies dat net als de mens ook dieren allerlei vormen van sociaal gedrag vertonen, van een eigen taal tot het hebben van gevoelens. In dat opzicht meent filosoof René Ten Bos (2017) dat het woord 'antropoceen' met een kleine letter moet worden geschreven, omdat een hoofdletter te veel eer is voor mensen: verdienen we het wel om een tijdperk naar ons zelf te noemen als 'beloning' voor de rotzooi die we maken?

Auteurs als Bruno Latour (2005) en Timothy Morton (2018) hebben laten zien dat hele idee van een onderscheid - tussen subject en object en daarmee samenhangende 'moderne' onderscheidingen zoals mens/technologie, cultuur/natuur, politiek/wetenschap en mens/dier - volstrekt kunstmatig is geworden. In plaats van vast te houden aan dergelijke strikte dichotomieën stelt Latour voor te spreken vanuit 'hybriden' of 'assemblages' om van daaruit de totstandkoming van nieuwe ordeningen of regimes te begrijpen. In dat licht moet ook Latours voorstel worden begrepen voor 'het parlement van de dingen', een idee dat hij in de jaren 1990 bedacht om alles wat 'niet-mens' is een stem te geven in de politieke besluitvorming. In de bundel Het parlement van de dingen (2020) ziet Latour een belangrijke rol hierbij weggelegd voor wetenschappers. Zo kunnen wetenschappers in dit parlement de belangen vertegenwoordigen van bijvoorbeeld de Veluwe of van ecosystemen om zo alles wat 'sprakeloos' is een stem te geven (Schuilenburg, 2021). Een interessant experiment hiermee vindt momenteel in Nederland plaats met 'de Ambassade van de Noordzee', waarin de dingen, planten, dieren en mensen in en rond de Noordzee een stem krijgen. Achterliggende gedachte is dat de Noordzee en het leven in de zee van zichzelf is. Veel ecologische vraagstukken worden echter vanuit de natiestaat bekeken. Natiestaten zijn aan elkaar verantwoording schuldig, maar niet aan niet-menselijk leven. Dit experiment tracht hierin verandering te brengen door onder meer onderzoek en activiteiten te stimuleren waarin dit probleem van falende representatie van andere soorten in onze democratie aan de kaak wordt gesteld. ${ }^{1}$

Kijken we kritisch naar het onderscheid tussen mens en dier, dan leidt dit onoverkomelijk tot de vraag hoe de criminologie hiermee omgaat. In de criminologie waarschuwen verschillende kritische denkers ons ervoor om niet de eigen soort centraal te stellen. Dat is speciesistisch. Daartegenover staat het non-speciesisme. Wortels voor dit denken liggen in het denken over dierenrechten en -welzijn, waarin krachtig beargumenteerd is dat dieren geen gebruiksvoorwerpen zijn (Singer, 1975; Regan, 1983). In de criminologie is Piers Beirne een belangrijke voorvechter van het non-speciesisme. Hij stelt dat dieren er niet zijn voor mensen, maar ervoor zichzelf toe doen. In de criminologie hebben we wat hem betreft echter nog een lange weg te gaan, zo schrijft hij: 
'[W]hen animals appear in criminology they are almost always passive, insentient objects acted upon by humans. Discursively, as objects of human agency, animals reflect or are drawn into some aspect of the complex web of human animal relationships, that is deemed problematic or undesirable' (2007: 61$62)$.

Beirne heeft verschillende criminologen beïnvloed, waaronder het werk van Ragnhild Sollund (2011), Geertrui Cazaux (2001/2002) en Janine Janssen (2019). Inmiddels heeft de aandacht voor andere soorten naast de mens een thuis gevonden bij de groene en kritische criminologie. Gelet de belangstelling in deze hoek voor processen van sociale uitsluiting en emancipatiebewegingen, ligt dat ook voor de hand (Cazaux, 2001/2002; Beirne, 2007; White, 2011, 2013).

\section{$5 \quad$ Is de mens een bijzonder dier?}

Hoewel criminologen steeds meer aandacht besteden aan zaken als het welzijn en de mishandeling van dieren, kan niet gesteld worden dat het non-speciesisme veel vaste voet aan de grond heeft gekregen. Vaak vindt onderzoek naar dieren plaats omdat er belangen van mensen in het geding zijn. Zo is het meest onderzochte onderwerp op het gebied van mens-dierrelaties, de zogeheten cruelty link. Bij die link gaat het om de gedachte dat geweld tegen dieren een voorspeller kan zijn van geweld tegen mensen. Maar verdient het leed dat dieren ondergaan alleen aandacht vanwege die voorspellende waarde? Doen die dieren er dan an sich niet toe? En waarom maken we ons vooral in dit verband zorgen om kleine huisdieren en niet om de dieren waar jagers op schieten of die in een slachthuis eindigen (Cazaux, 2001/2002)? Dat laatste punt van kritiek laat zien dat niet alle dieren criminologen even veel aan het hart gaan. De ene soort spreekt ons meer aan dan de andere en daar lopen we dan ook harder voor (Herzog, 2010). De Nederlandse bioloog Edo Knegtering (2009) vraagt zich in zijn proefschrift daarom af aan welke uiterlijke kenmerken dieren moeten voldoen, willen ze de meeste kans maken op bescherming door de overheid. Aantrekkelijk gevonden worden door mensen, dat wil zeggen over mooie veren of een vacht beschikken, blijkt belangrijk te zijn om te kunnen rekenen op bescherming van en tegen onze soort.

Het is ontzettend moeilijk om buiten je eigen soort te treden en zonder enige vorm van waardeoordeel het leven om ons heen waar te nemen. In feite kan dat niet. Instinctief weten we dat een leeuw nu eenmaal gevaarlijker is dan een huiskat. Het gegeven dat we de wereld en het leven om ons heen ordenen en classificeren is dan ook zo gek nog niet. Als we dat niet hadden geleerd, waren we als soort waarschijnlijk al lang van deze planeet verdwenen. Wat voor veel mensen echter lastig is, is om zichzelf als dier onder de dieren te zien. Als mensen zich al als dier zien, dan vaak als een bijzonder en superieur dier (Midgley, 1979; Thomas, 1990; Bourke, 2011). Het gaat hierbij om het Human Exemptionalism Paradigm (HEP) (Dunlap \& Catton, 1994). Aan de ene kant hebben biologen sterk de hand gehad in de ontwikkeling van HEP. Zij kwamen met een indeling van leven, waarbij eencelligen onderaan staan en aan de top van de piramide de mens. Aan de andere kant is er ook kritiek geuit op dierenactivisten die zich inzetten voor het toekennen van specifie- 
ke rechten aan andere soorten, waarop tot dan toe alleen mensen recht konden doen gelden. Joan Dunayer (2004) spreekt zelfs van 'new specisisme', waarbij dieren die het dichtst bij ons staan - vooral primaten - omdat ze bijvoorbeeld bewustzijn hebben en pijn kunnen voelen, meer rechten krijgen dan andere soorten.

\section{$6 \quad$ Moet het allemaal anders?}

De problemen waar we voor staan, zijn immens. We kunnen het ons echter niet permitteren om moedeloos te worden, want dat leidt tot inactiviteit. We staan ook niet volledig met lege handen. Door verschillende auteurs is aangegeven dat de criminologische wetenschap niet volledig op de schop hoeft, als er ook serieuze aandacht wordt besteed aan andere soorten (Janssen, 2019). In de eerste plaats zullen we kritisch ons taalgebruik onder de loep moeten nemen en niet langer over mensen en dieren spreken, maar over mensen en andere dan menselijke dieren (Beirne, 1996; Beirne et al., 2018). In de tweede plaats zullen we in onderzoek ook meer kleur moeten bekennen ten aanzien van onze motieven: zetten we ons in voor het menselijk belang of is dat van andere soorten net zo belangrijk (Janssen, 2019)? Deze twee punten hebben invloed op een derde punt: het conceptuele en theoretische kader waarmee onderzoek wordt gedaan. Maar er is nog een vierde aspect: op methodologisch gebied zal er veel aan de gereedschapskist van criminologen moeten gebeuren, willen we daadwerkelijk goed inzicht krijgen in de ervaringen van andere soorten. Niet zo lang geleden heeft Frans de Waal (2016) laten zien hoe moeilijk het is om onderzoek te doen naar de intelligentie van andere soorten. De titel - Zijn we slim genoeg om te weten hoe slim dieren zijn? - moet begrepen worden als een retorische vraag, want het antwoord is een volmondig 'nee'. De Waal laat zien welke bokken wetenschappers geschoten hebben bij het inschatten van de cognitieve vermogens van andere soorten. Die schattingen vielen overigens nooit te hoog uit. De Waal stelt dat we andere soorten consequent onderschatten en bijgevolg onszelf overschatten. Dat zal nog een groot obstakel zijn bij het verzetten van de bakens in de richting van een non-speciesistische criminologie in het antropoceen.

Kortom, het antropoceen roept allerlei criminologische vragen op. Vragen over dader- en slachtofferschap, over in te zetten technologie, methoden van onderzoek en de invulling van een veilig en gezond leven. Dergelijke vragen komen ook in de groene en kritische criminologie aan bod, maar wat het antropoceen hieraan toevoegt, is hoe onomkeerbaar de menselijke invloed op aarde is en de wijze waarop alles met elkaar verknoopt is geraakt. Zo stelde de Wereldbank dat door de klimaatopwarming massa-immigratie op gang zal komen, wat weer kan leiden tot grootschalige conflicten en oorlogen. De schattingen lopen uiteen, maar naar schatting rond de 140 miljoen mensen zullen op de vlucht gaan slaan door klimaatopwarming. Hiervoor is uitvoerig het actuele voorbeeld van zoönosen aangehaald, die mede ontstaan door de illegale handel in bedreigde soorten en het verkleinen van het leefgebied van andere soorten door illegale boskap (Boekhout van Solinge, Van Impe, Janssen \& Van Uhm, 2020). Het ligt dan ook in de lijn der verwachting dat na de coronacrisis nieuwe pandemieën zullen uitbreken, omdat mens en dier steeds meer in elkaars vaarwater terechtkomen (Quammen, 2020). Die ziektes zijn na- 
tuurlijk slecht nieuws voor de mensen, maar een criminologie van het antropoceen vraagt zich ook af wat dit voor die andere soorten zelf betekent. Hoe kunnen we met andere woorden ecoïsten worden?

\section{Een manifest voor de criminologie}

De grote zorgen waar we voor staan, moeten ons niet verlammen. Integendeel, criminologen moeten net als andere wetenschappers hun verantwoordelijkheid nemen. Wij denken dat dit het volgende voor de criminologie in de $21^{\mathrm{e}}$ eeuw betekent.

Doel van de criminologie in het antropoceen

- Het leveren van een bijdrage aan het stoppen van de desastreuze invloed van mensen op de aarde en haar bewoners. Om dat doel te bereiken moeten criminologen nadenken over de aandachtsgebieden van de criminologie, theorie, methodologie en criminologisch onderwijs. Die punten worden hieronder een voor een uitgewerkt.

\section{Aandacht van de criminologie: criminologie gaat niet alleen over mensen}

- Andere soorten, leven en ecosystemen doen erop zichzelf toe en niet alleen vanwege door mensen gepercipieerd (economisch) nut. De criminologie dient daarom het onderscheid tussen menselijk en ander leven te overstijgen.

- Aandacht voor de invloed van menselijk gedrag op andere bewoners van de aarde is criminologisch relevant. Dit impliceert een verbreding van het begrip 'slachtoffer': slachtofferschap kan niet alleen voorbehouden zijn aan mensen.

\section{Theorie}

- In criminologische theorieën zal het denken in klassieke dichotomieën moeten worden doorbroken, van het onderscheid tussen mens/dier tot dader/slachtoffer.

- In criminologische theorieën zal de scoop verder moeten reiken dan het menselijk doen en laten. Gevolgen van menselijk handelen voor andere soorten, leven en ecosystemen dient bovendien onderdeel te zijn van criminologische theorievorming.

\section{Methodologie}

- In de methodologie dient rekening te worden gehouden met (on)mogelijkheden om de ervaringen van andere soorten in kaart te brengen. Dat betekent onder meer dat criminologen - meer dan tot op heden het geval is - zich ook open moeten stellen voor de methodologische kennis van andere disciplines, zoals die van de biologie en de zoölogie.

\section{Onderwijs}

- Daar waar theorie en methodologie een belangrijke rol spelen in het criminologische onderzoek, mag ook het onderwijs dat criminologen aan hogescholen en universiteiten verzorgen niet over het hoofd worden gezien. In dat onder- 
wijs liggen voor criminologen belangrijke kansen om aandacht voor het antropoceen te (blijven) voeden. Randvoorwaarde is wel dat bij de programmering van onderwijs de gevolgen van het antropoceen als relevant thema worden gezien.

\section{Bijdragen aan dit themanummer}

Met dit themanummer willen wij niet alleen de noodzaak van criminologische aandacht voor het antropoceen onderstrepen. Doel is ook om iets te laten zien van de variëteit en rijkdom van het criminologische onderzoek in het antropoceen en waar dat onderzoek zich nog meer op kan richten.

In het openingsartikel van Yanna Hoek, Daan van Uhm en Damián Zaitch staat de Nederlandse rechtszaak Urgenda centraal. De auteurs laten zien dat in het vonnis van de rechter de belangen van de mens nog steeds voorop worden gesteld. Ze spreken in dit verband van het 'antropocentrische karakter' van het recht. Tegelijk menen de auteurs dat de uitspraak een belangrijke steun in de rug is voor de erkenning van het slachtofferschap van zowel natuur als mens door klimaatopwarming vanuit een internationaal perspectief. Vervolgens belichten Anantha Thelen en Fiore Geelhoed het onderwerp 'activisme' in het antropoceen. In hun empirische onderzoek naar de internationale organisatie Anonymous for the Voiceless wordt gewezen op de verschillende spanningen die bestaan binnen de Nederlandse tak ervan. In het bijzonder gaat het hierbij om de spanning tussen de presentatie naar buiten toe en de interne dynamiek tussen de leden. Zo wordt de indruk gewekt van een toegankelijke beweging waar je in two steps aan kan deelnemen, maar een belangrijke voorwaarde voor deelname ervan blijkt een streng veganistische levensstijl te zijn.

Lieselot Bisschop gaat in op daderschap in het antropoceen. Criminologen hebben een warme belangstelling voor het aanwijzen van plegers van grensoverschrijdend gedrag, maar Bisschop laat zien dat dat niet altijd eenvoudig is om een individuele verantwoordelijke aan te wijzen waar het gaat om het aanbrengen van schade aan het milieu. Ze houdt daarom een drietrapsmodel aan, beginnend op het systeemniveau (macro) en afdalend naar het organisatorische (meso) en individuele (micro) niveau. Binnen elk van deze niveaus reflecteert Bisschop over wat we anders zouden kunnen doen om daderschap in het antropoceen beter te vatten.

In het essay De Green New Deal gaat Merijn Oudenampsen in op de politieke ambities om de $\mathrm{CO}^{2}$-uitstoot te reduceren. De Green New Deal is een investeringsprogramma, met als doel om zowel de samenleving te verduurzamen als mensen meer werkzekerheid en toegang tot zorg te geven. Inmiddels heeft de Europese Unie zich gecommitteerd aan een European Green Deal en werkt Joe Biden aan gelijksoortige plannen onder de noemer Clean Energy Revolution. Oudenampsen gaat in op de vragen die dit nieuwe 'sociaal contract' oproepen. Hij wijst onder meer erop dat een dergelijk plan alleen kans van slagen heeft als we de economie anders gaan denken. Femke Wijdekop en Anneke van Hoek betrekken het antropoceen op het herstelrecht. Zij beargumenteren dat de milieucrisis duidelijk maakt dat onze huidige juridische instrumenten en begrippen niet voldoen om de op grote schaal veroorzaakte milieuschade zowel effectief te bestrijden als te herstellen en te voorkomen. 
Zij pleiten voor een 'positieve groene criminologie' en gaan uitgebreid in op de mogelijkheid om daarbij zo veel mogelijk herstelgericht te werken in zaken waarin milieuschade is veroorzaakt. Joost Leuven, Eva Meijer en Bernice Bovenkerk vragen in hun essay aandacht voor dieren in het antropoceen. In de dierethiek bestaat een tendens om dieren niet langer als passieve en lijdende subjecten te zien. Dieren hebben namelijk agency, handelend vermogen. Aan de hand van een kritische analyse van het houden van dieren in dierentuinen, laten zij de dubbele houding van mensen jegens andere soorten zien: om soorten voor uitsterven te behoeden, sluiten we ze op in dierentuinen, waar we de vrijheid om te handelen ernstig beperken. Vervolgens neemt Sander Kole ons in zijn essay mee naar het plantenrijk. Ook planten hebben het in het antropoceen zwaar te verduren. Kole besteedt met name aandacht aan de juridische mogelijkheden om planten en habitats te beschermen. Hij laat zien dat veel (internationale) wet- en regelgeving een ambivalent karakter heeft. De belangen van mens en economie staan vaak voorop, met als gevolg dat beschermingsmaatregelen relatief eenvoudig terzijde worden geschoven. Stephen Snelders en Nick Verouden buigen zich in hun essay over de vraag hoe in het antropoceen disciplines als geschiedenis en antropologie kunnen bijdragen aan nieuwe onderzoeksperspectieven. Zij geven aan dat nieuwe perspectieven nodig zijn om de antropocentrische dichotomie tussen het sociale en de natuur te kunnen overstijgen. Daartoe worden pogingen gedaan in de transspecies history, transspecies ethnography en transspecies narratology. Daarnaast moeten we ons tijdsperspectief kritisch onder de loep nemen. Dat is nogal kort, maar om daadwerkelijk inzicht te krijgen in de wisselwerking tussen onze omgeving en ons eigen handelen, zullen we verder moet kijken dan onze eigen levensduur.

In de rubriek 'Significant Others' brengt Maartje Weerdesteijn verslag uit van haar interview met Susan Karstedt. Karstedt staat bekend om haar onderzoek naar de invloed van democratie op geweld in de maatschappij. In dat verband besteedde zij onder meer aandacht aan de Holocaust en andere internationale misdrijven en de rol van emoties bij (overgangs)justitie. Ook Karstedt gaat niet voorbij aan door mensen aangerichte ecologische rampspoed, maar in het interview uit zij haar bedenkingen bij de term 'ecocide'. In de rubriek 'Voorbij de horizon' bespreekt Toine Spapens wat het antropoceen betekent voor de criminologie aan de hand van drie recent verschenen boeken over dit thema. Aan de hand hiervan pleit Spapens ervoor om meer mainstreamtheorieën vanuit de criminologie te betrekken bij het debat over het antropoceen, waaronder de zelfcontroletheorie en de gelegenheidstheorie bij het zoeken naar verklaringen voor het gedrag van bedrijven. Ook de sociale desorganisatietheorie kan een raamwerk bieden om meer onderzoek te doen naar de gevolgen van klimaatverandering en ecologische destructie.

Tot slot laat de rubriek 'Doka' zien hoe de coronapandemie en de ecologische crisis volledig met elkaar zijn verknoopt.

\section{Literatuur}

Beirne, P. (1996). A note on speciesist language and (nonhuman) animal abuse. The Critical Criminologist, 7(1), 7-8. 
Beirne, P. (2007). Animal rights, animal abuse and green criminology. In P. Beirne \& N.South (Eds.). Issues in green criminology. Confronting harms against environments, humanity and other animals (pp. 55-83). Cullompton: Willan Publishing.

Beirne, P., I. O'Donnel, \& J. Janssen (2018). Murdering Animals. Writings on Theriocide, Homicide and Nonspeciesist Criminology. London: Palgrave Macmillan.

Boekhout van Solinge, T., I. van Impe, J. Janssen, \& D. van Uhm (2020). Een groen criminologisch perspectief op de Covid-19 pandemie. De Criminoloog. Nieuwsbrief van de Nederlandse Vereniging van Criminologie, 23, 4-5.

Bonneuil, C. \& J.-B. Fressoz, (2017). The Shock of the Anthropocene. The Earth, History, and Us. London \& New York: Verso Books.

Bos, R. ten (2017). Dwalen in het antropoceen. Amsterdam: Boom.

Bourke, J. (2011). What it means to be human. Reflections from 1791 to the present. London: Virago Press.

Cazaux, G. (2001/2002). Anthropocentrism and speciesism regarding animals other than human animals in contemporary criminology. Analysing the concept 'animal abuse' in criminological science and Belgian legislation regarding the protection and welfare of animals. Gent: University of Gent, Faculty of Law.

Dunlap, R.E. \& W.R. Catton (1994). Struggling with human exemptionalism: The rise, decline and revitalization of environmental sociology. The American Sociologist, 25(1), 5-30.

Guattari, F. (2000). The Three Ecologies, London: Athlone Press.

Haraway, D., N. Ishikawa, S.F. Gilbert, K. Olwig, A.L. Tsing \& N. Bubandt (2016). Anthropologists Are Talking - About the Anthropocene. Ethnos, 81(3), 535-564.

Hassler-Forrest, D. (2019). Cultuur en politiek in het antropoceen. In M. Schuilenburg \& S. van Tuinen (Red.). Leven in het antropoceen. Een handleiding (pp. 39-55). Amsterdam: Boom.

Herzog, H. (2010). Some we love, some we hate, some we eat. Why it's so hard to think straight about animals. London: Harper Perennial.

Huber, M.T. (2008). Energizing historical materialism: Fossil fuels, space and the capitalist mode of Production. Geoforum, 40(1), 105-115.

Janssen, J. (2019). Waarom de criminologie mij dierbaar is. Een persoonlijk pleidooi voor non-speciesisme. Den Haag: Boom Criminologie.

Klein, K. (2014). This Changes Everything: Capitalism vs. the Climate. New York: Simon \& Schuster.

Knegtering, E. (2009). The featheries and the furries: species characteristics and tendencies in public species conservation. Groningen: University of Groningen.

Latour, B. (2005). Reassembling the Social. An Introduction to Actor-Network Theory. Oxford: Oxford University Press.

Latour, B. (2020). Het parlement van de dingen. Over Gaia en de representatie van niet-mensen. Amsterdam: Boom Filosofie.

Malm, A. (2016). Fossil Capital: The Rise of Steam Power and the Roots of Global Warming. London: Verso.

Malm, A. \& A. Hornborg (2014). The Geology of Mankind? A Critique of the Anthropocene Narrative. The Anthropocene Review, 1(1), 62-69.

Midgley, M. (1979). Beast and Man. The Roots of Human Nature. Brighton: The Harvester Press Limited.

Moore, J.W. (2015). Capitalism in the Web of Life: Ecology and the Accumulation of Capital. London: Verso.

Moore, J.W. (2017). The Capitalocene, Part I: On the Nature and Origins of Our Ecological Crisis. The Journal of Peasant Studies, 44(3), 594-630.

Morton, T. (2018). Duistere ecologie: voor een logica van de toekomstige co-existentie. Amsterdam: Boom. 
Quammen, D. (2020). Zoönose. Hoe dodelijke ziekten van dier naar mens overspringen. Amsterdam: Atlas Contact.

Regan, T. (1983). The case for animal rights. Berkeley: University of California Press.

Schuilenburg, M. (2020), Versnelling van wat we al zagen. Tijdschrift voor Sociale Vraagstukken, 2, 4-7.

Schuilenburg, M. (2021, n.n.g.). De hybride en het klimaat. Het belang van Bruno Latour voor de criminologie. Tijdschrift voor Criminologie.

Schuilenburg, M. \& S. van Tuinen (2019). Leven in het antropoceen. Een handleiding. Amsterdam: Boom.

Singer, P. (1975). Animal liberation. A new ethics for our treatment of animals. New York: Harper Collins.

Sollund, R. (2011). Expressions of speciesism: the effects of keeping companion animals on animal abuse, animal trafficking and species decline. Crime, Law and Social Change, 55(5), 437-451.

Thomas, K. (1990). Het verlangen naar de natuur. De veranderende houding tegenover planten en dieren. 1500-1800. Amsterdam: Agon.

Waal, F. de (2016). Zijn wij slim genoeg om te weten hoe slim dieren zijn? Amsterdam: Uitgeverij Atlas Contact.

White, R. (2011). Transnational environmental crime. Towards an eco-global criminology. New York: Routledge.

White, R. (2013). Environmental harm: An eco-justice perspective. Bristol: Policy Press. 